\title{
The debris flow in Log pod Mangartom, NW Slovenia
}

\author{
M. Zorn \& B. Komac \\ Anton Melik Geographical Institute, Scientific Research Centre of the \\ Slovenian Academy of Sciences and Arts, Slovenia
}

\begin{abstract}
In November 2000, heavy rains in Slovenia triggered numerous slope processes. Among the largest were the landslide and debris flow in Log pod Mangartom in western Slovenia. This paper describes the main geographical, geological, and geomechanical features of the debris flow, detailing its causes and describing the consequences. The facts presented in the article demonstrate that intensive geomorphic processes are relatively frequent phenomena and are an important factor in the transformation of the surface in alpine regions.

Keywords: geography, geomorphology, natural hazards, slope processes, debris flow, landslide, Log pod Mangartom, Slovenia.
\end{abstract}

\section{Introduction}

Log pod Mangartom (651 m; population about 130) is a nucleate roadside settlement located on the right bank of the Koritnica River on the alluvial fan of its tributary Predelica stream. On November 17, 2000, a debris flow struck the village. According to Ogrin [11], the Koritnica Valley has a temperate continental climate. Between 1961 and 1990, an annual average of 2,500 $\mathrm{mm}$ of precipitation was recorded, and avalanches regularly threaten the valley floor [13]. The area is part of Triglav National Park.

\section{Debris flow}

At 12:45 on November 15, 2000, a landslide was triggered west of Mount Mangart $(2,679 \mathrm{~m})$ above the valley of the Mangartski Potok stream, which has an inclination greater than $10 \%$. The landslide stopped almost two kilometers 
lower at the valley's junction with the Predelica Valley. Lying between the altitudes of 1,340 and 1,580 meters, the original site of the slide material was 900 meters long and three to four hundred meters wide. The average thickness of the slide in source area was ten meters, and it reached forty meters in places. In all, 1.5 million cubic meters of material was shifted [6]. Above the slide, crown cracks appeared that extended to the watershed divide ridge.

Due to the heavy rain, the streams grew greatly. For 35 hours and 20 minutes, water soaked the slide material deposited on the floor of the Mangartski Potok valley until it became liquefied on November 17, 2000. A few minutes after midnight, a debris flow was triggered that traveled almost three kilometers downwards at a speed approaching eight meters per second [17].

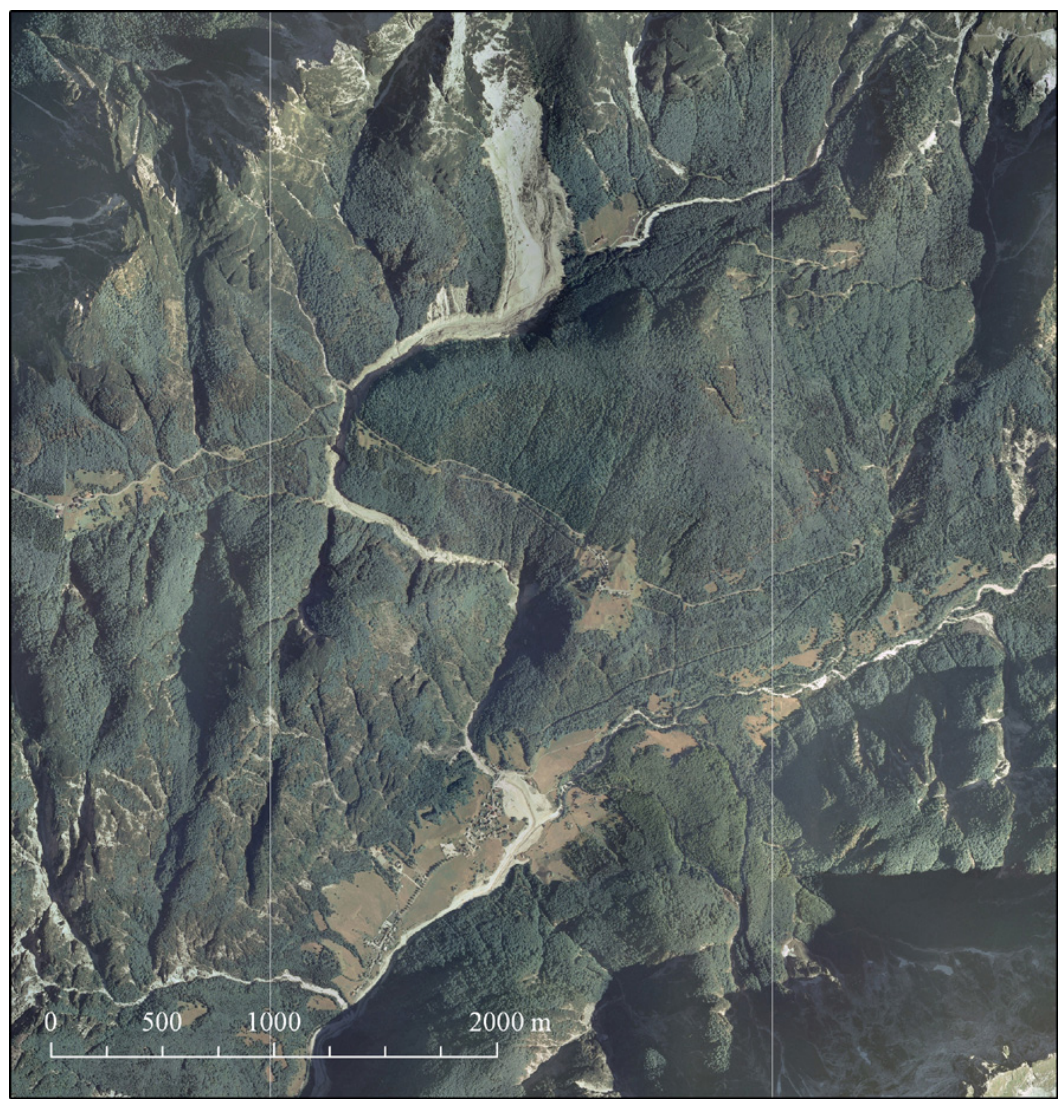

Figure 1: Aerial photograph of the event. (Source: Orthophotographic image, (C) Geodetic Survey of Slovenia, 2005.)

\subsection{Primary reasons and causes of the debris flow}

The primary cause of the debris flow was heavy and intense precipitation. The rain gauge in the village of Log pod Mangartom recorded 1,638.4 $\mathrm{mm}$ of rainfall 
(more than $60 \%$ of the average annual precipitation) in the 48 days before the events. This amount of recorded rainfall has a recurrence interval of more than 100 years. The increase in runoff coefficients in the autumn of 2000 during the rainy period before the landslide was therefore two- to threefold higher than usual. Additional water was contributed by the permanent but slow seepage of underground water from a reservoir in the slope [8]. Abundant flow of water in the body of the landslide located in the Mangartski Potok valley that created a state of liquefaction [14].

An important cause of this event is the geological structure, particularly the 100- to 200-meter thick layers of Julian-Tuval limestone, marlaceous limestone, marl, and schist claystone. These so called Tamar or Rabelj (Raibl) layers alternate in the 700-meter deep stratified, tectonically damaged, and porous Karnian and Norian dolomite. At their contact are springs that are an added significant cause of landslides. The tectonically damaged rock also makes the slopes unstable [3].

The clay minerals of the Tamar layers absorb water and swell and the schist claystone decomposes into clay, which leads to sliding. The low plasticity creeping material contains $20-30 \%$ fine particles $(<63 \mu \mathrm{m})$ and is thixotropic. With a small increase in moistness, the viscosity and shear limit drop very rapidly and therefore the material liquefies with only small changes in its water content. Approximately 33\% moisture is sufficient to cause liquefaction [7].

Table 1: $\quad$ Main geotechnical parameters of the debris flow deposit [8].

\begin{tabular}{|l|r|}
\hline Specific gravity & $27-28.5 \mathrm{kN} / \mathrm{m}^{3}$ \\
\hline Average unit weight of in situ samples & $\sim 22 \mathrm{kN} / \mathrm{m}^{3}$ \\
\hline Average dry unit weight & $18 \mathrm{kN} / \mathrm{m}^{3}$ \\
\hline Porosity of material in situ & $34 \%$ \\
\hline Water content of material in situ & $34 \%$ \\
\hline Degree of saturation of material in situ & $100 \%$ \\
\hline Hydraulic conductivity & $<25 \cdot 10^{-6} \mathrm{~m} / \mathrm{s}$ \\
\hline
\end{tabular}

Among the causes of the landslide, we cannot completely exclude the influences of the fissures that developed in the slopes after the "Easter earthquake" of April 12, 1998, after which water was able to flow more rapidly into the depths $[10,22]$. Also, the fissures may have changed or opened new groundwater pathways through fractured dolomite layers in the slope [8]. A lack of vegetation cover also causes greater erodibility and vulnerability to landslides. The area, including the slide area, was overgrown with forest, which could have influenced the change in the water conditions. However, several decades ago the area was clearcut, and today Norway spruce (Picea abies) grows instead of beech (Fagus sylvatica). The mass of wood did not influence the stability of the slopes, however, since it only comprised $1 / 100,000$ of the entire mass of the material in the landslide [4]. 
128 Monitoring, Simulation, Prevention and Remediation of Dense Debris Flows II

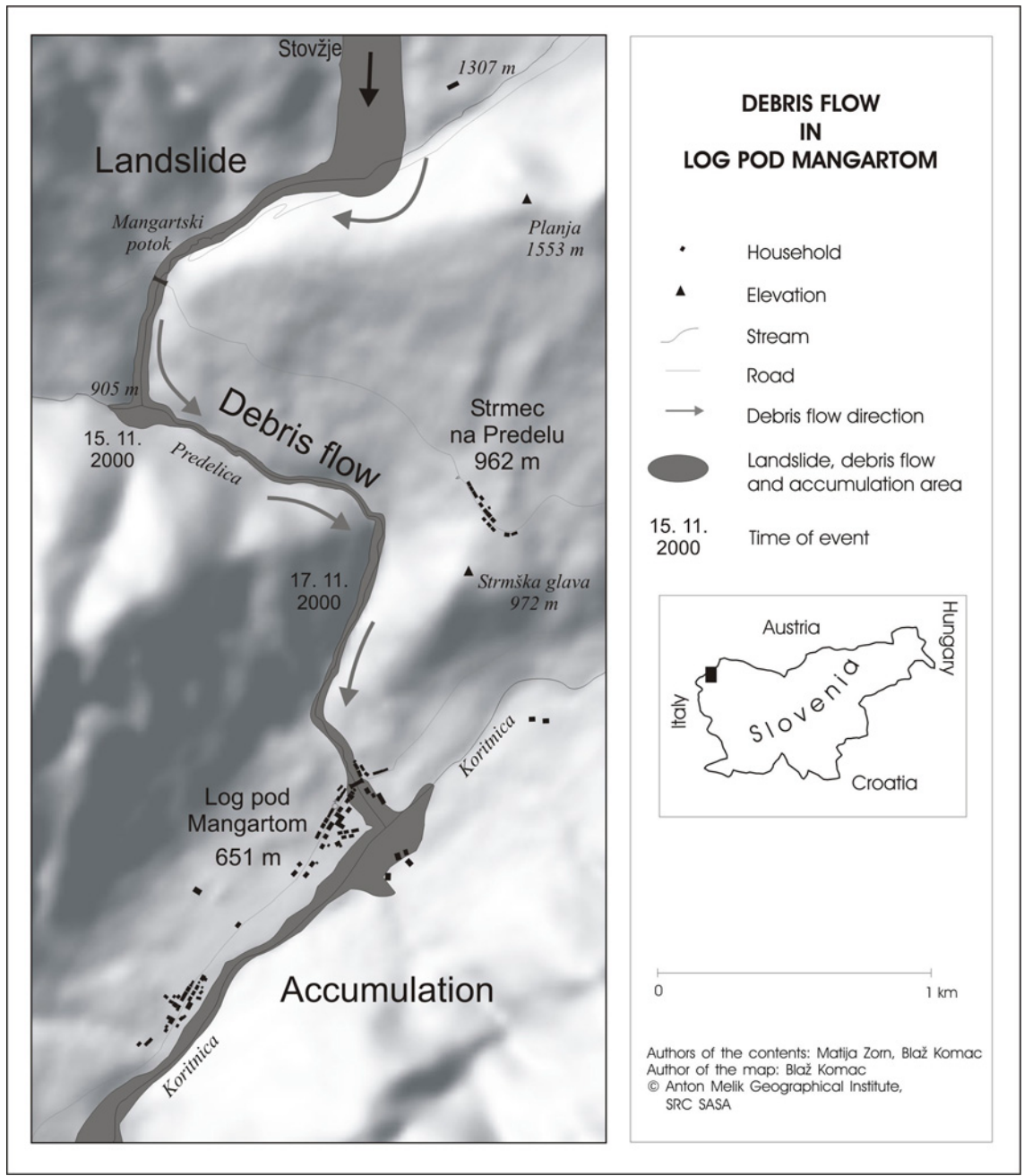

Figure 2: $\quad$ Map of the Log pod Mangartom landslide and debris flow.

\subsection{Consequences of the debris flow}

The annual sediment production in the headwaters of alpine valleys in western Slovenia is estimated to average $>1,000 \mathrm{~m}^{3} \mathrm{~km}^{-2} \mathrm{a}^{-1}$, which means that rock falls and debris flows are an important factor in the transformation of alpine regions. Large amounts of material are usually transferred to lower sites in a very short time.

After the 1998 earthquakes in the Soča Valley, about $260,000 \mathrm{~m}^{3}$ of rock fall material was expected to remain in its original position, while an estimated volume of $480,000 \mathrm{~m}^{3}$ could possibly be released to watercourses over a longer period during extreme events. About $200,000 \mathrm{~m}^{3}$ of rock fall debris was 
deposited in areas from where the material could be released to watercourses during future rainfall events [9].

During the debris flow in 2000, a total of 1.5 million cubic meters of material moved. Part of the material was deposited in the bed of the Predelica stream, and more that a million cubic meters was deposited over an area of fifteen hectares in the Koritnica Valley (Figure 4). For almost three kilometers, the valley floor was covered with a layer of alluvium several meters thick.

The Koritnica River carried off a great deal of sediment: above its confluence with the Koritnica, the Soča River near Kršovec contained only $104 \mathrm{~g} / \mathrm{m}^{3}$ of suspended material while at the confluence it contained $2,971 \mathrm{~g} / \mathrm{m}^{3}$. On November 21, 2000, the highest concentration ever recorded in the Soča, 8,112 $\mathrm{g} / \mathrm{m}^{3}$, was measured [20].

Mud flows formed in the deposited sediment to form a lake that threatened the Mangartska Planina mountain lodge. Similar "clay bombs" (Figure 3) could also be found in the Koritnica Valley, where they gradually deteriorated into characteristic conical mounds [2].

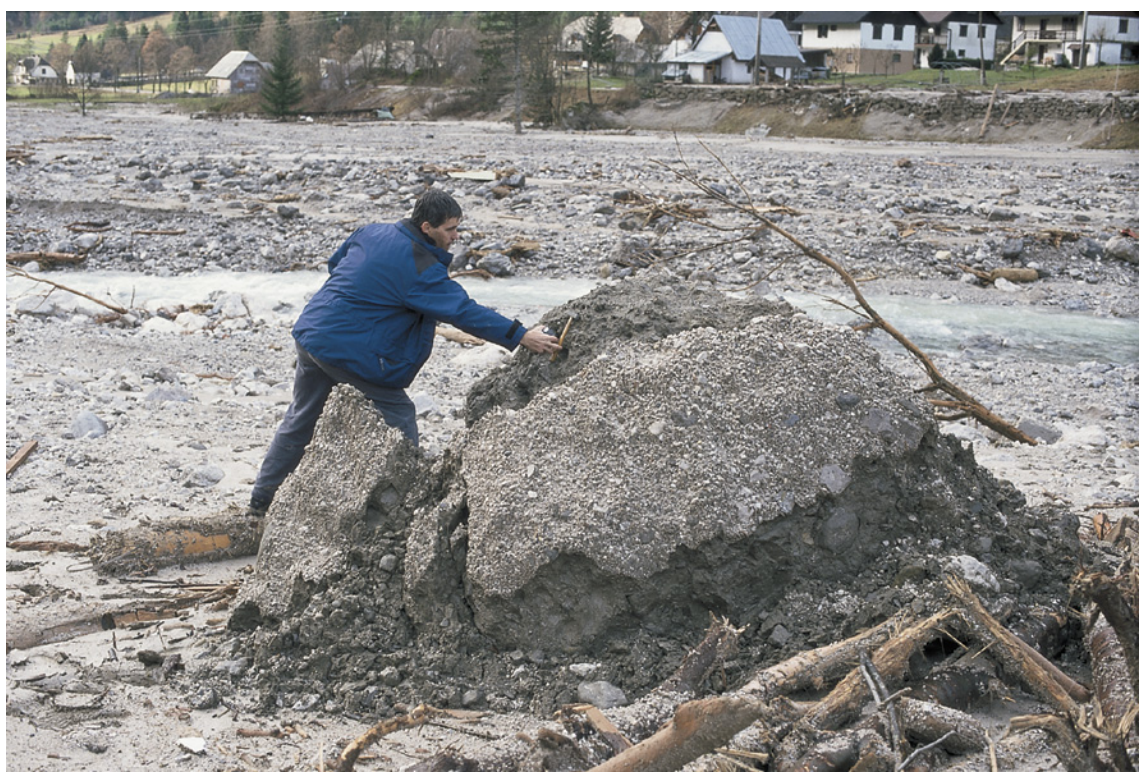

Figure 3: "Rubble-clay bomb" (Photograph: Blaž Komac, November 30, 2000).

The natural disaster in Log pod Mangartom claimed seven lives and demolished or damaged eighteen houses and eight outbuildings. Two bridges were destroyed on the Predel Pass road that links Bovec in Slovenia with Tarvisio in Italy. The damage amounted to 31 million euros [16].

Because television coverage aroused great public sympathy, access for locals was possible after a month and the area was completely open only three months after the disaster. Within this period, the streams in the slide area were regulated, 


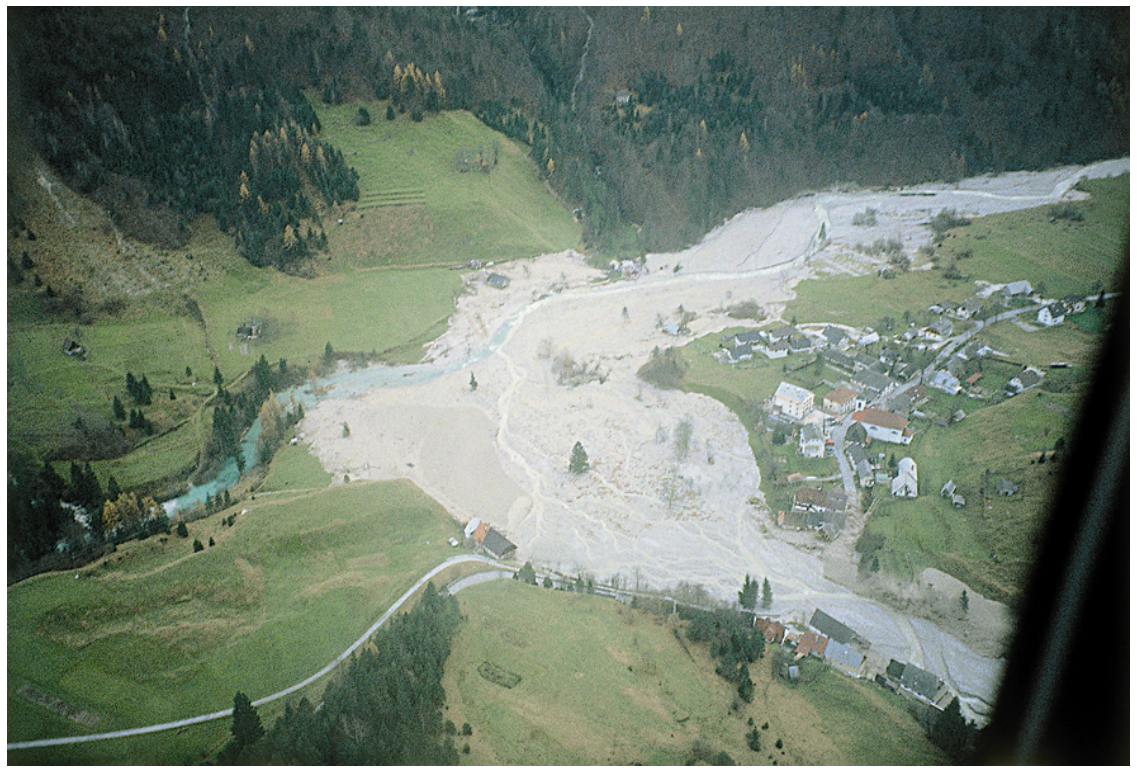

Figure 4: Debris flow fan at the confluence of the Predelica (right) and Koritnica (left) streams in Log pod Mangartom (Photograph: Blaž Komac, November 19, 2000).

the ruins removed, a landslide alarm system installed, and temporary bridges built with the help of the Slovene army [3].

After the debris flow, the Parliament of the Republic of Slovenia passed a law on dealing with the consequences of larger landslides, and in 2003 adopted a location plan for managing the area of the debris flow. Barriers were constructed in the Predelica Valley, and fifteen replacement houses were built in Log pod Mangartom for residents whose property had been destroyed. The reconstruction work and the anticipated interventions evoked some criticism, in particular that access to the valley was forbidden for three months, the procedure for developing the national location plan led by the Ministry of Environment did not allow local residents sufficient opportunity to participate, the solutions proposed were not all professionally grounded, and additional houses had to be destroyed for the construction of a new concrete bridge in the village. Furthermore, the final decisions on the building of houses only began in 2004, so people with destroyed homes had to wait several years before the construction of new houses was allowed.

\section{Conclusion}

The Log pod Mangartom disaster was one of the largest in Slovenia in recent decades since it claimed seven lives. It was unexpected, even though there have been many landslides in the area. The debris flow revealed lacustrine chalk, which shows that major geomorphological events have occurred in the Koritnica 
Valley in the past. These are also reflected in local site names such as "Meli," which means "scree" in English [5].

A similar event occurred almost three hundred years ago when a clay quarry was buried, resulting without a doubt in the cessation of pottery making in the village of Strmec na Predelu [5]. On August 26, 1891, "thick sand" destroyed a flourmill and sawmill at the confluence of the Predelica and Koritnica valleys. An innkeeper reported that the water carried away "all the yard up to the corner of the house and buried half of my barn. On the other side it buried an entire house." The disaster also carried away a house "from which came neither soul nor sound..." [22].

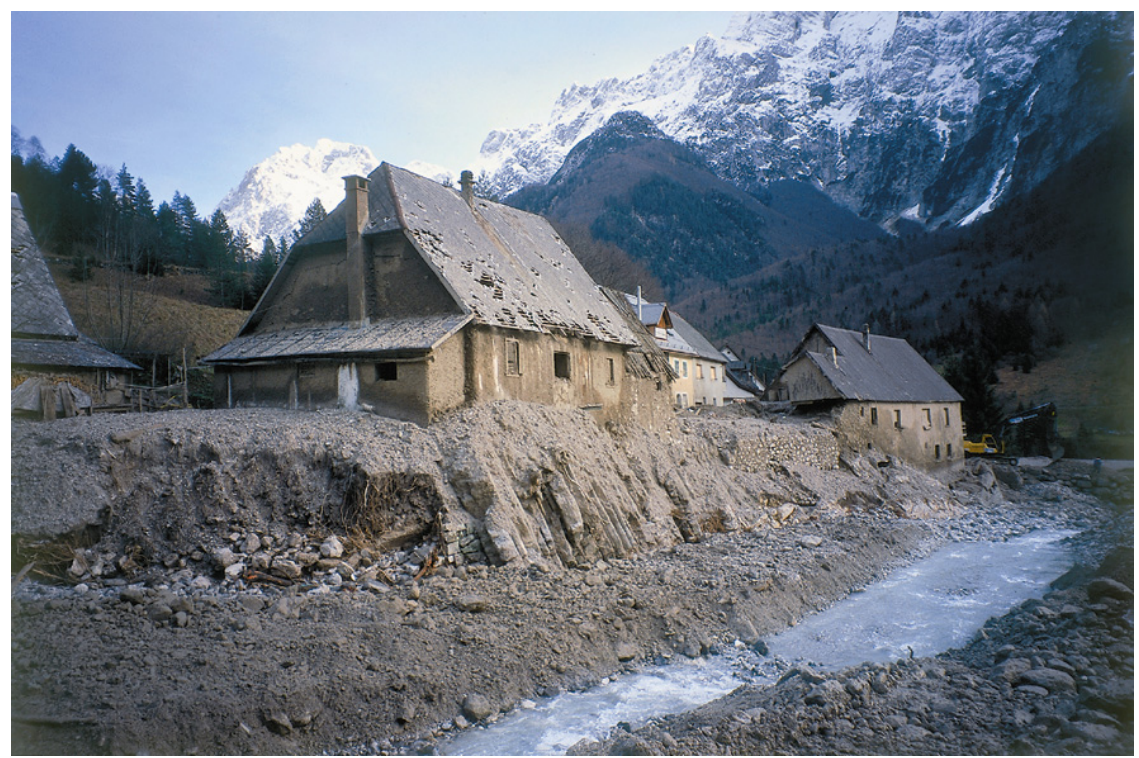

Figure 5: The debris flow destroyed or damaged 18 houses and 8 outbuildings (Photograph: Matija Zorn, November 30, 2000).

Similar events have occurred along the nearby Ugovizza stream (for example end of August 2003) in the Val Canale valley in Italy where sources from the end of the 18th century report debris flows. On the basis of historical data that stretches back to the 16th century, it has been determined that larger such events have a return period of twenty-five years and smaller ones form three to six years [19].

A link exists between the increasing occurrence of debris flows in the American state of Virginia and the period when the climate changed to the extent that it enabled the frequent penetration of warm tropical air masses to the central part of the Appalachian Mountains. In the canyons of the California deserts, debris flows occur almost once every thirty to one hundred years [18].

The activity of debris flows in Slovenia's Alps is also an indicator of climate change. Debris flows were very frequent during the penultimate glacial period, in the interglacial period, and after the last glacial period. The sediment from debris 


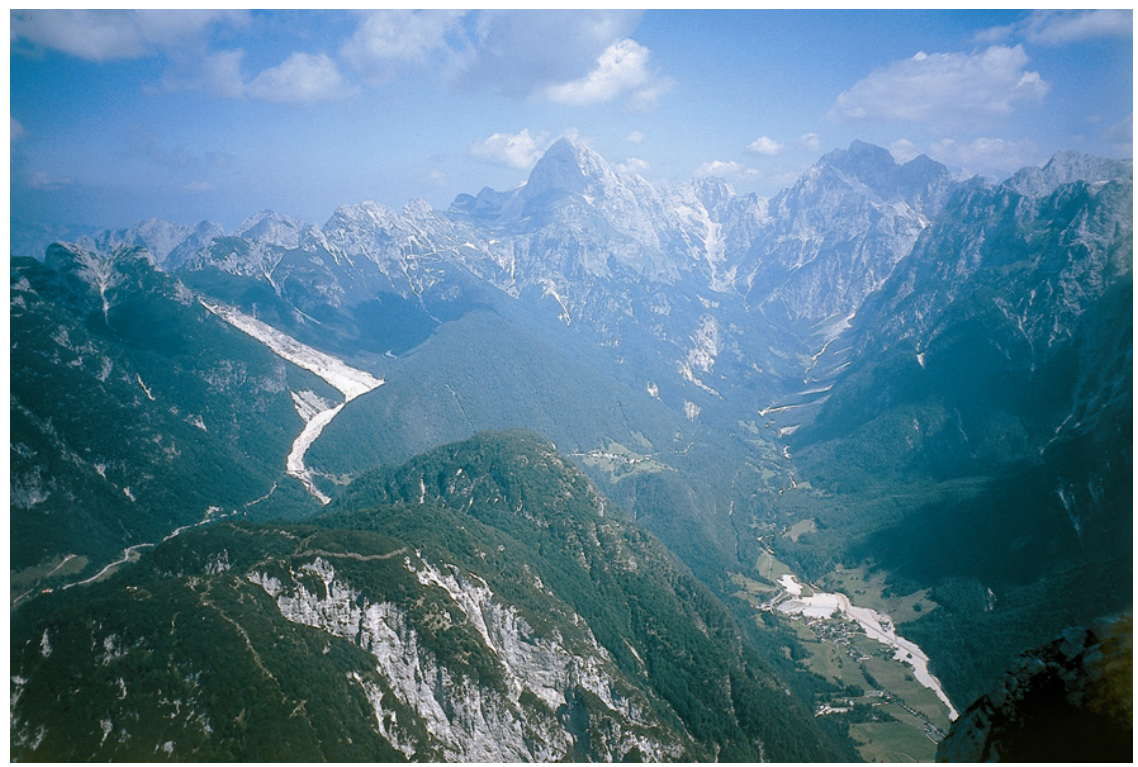

Figure 6: Mount Mangart (in the middle behind; 2,679 m) with landslide on the left and debris flow fan in Log pod Mangartom on the right (Photograph: Matija Zorn, August 25, 2001).

flows then covered the greater part of the nearby Bovec basin [1] and there were frequent large rock falls in the Julian Alps [21]. In the Vipava Valley, there was a landslide with a volume of around 150 million cubic meters [15].

With this in mind, it will be in the greatest interest to observe the changing frequency of these events relative to climate change in the near future as well.

\section{References}

[1] Bavec, M., Tulaczyk, S.M. Mahan, S.A. \& Stock, G.M., Late Quaternary glaciation of the Upper Soča River Region (Southern Julian Alps, NW Slovenia). Sedimentary geology 165(3-4), pp. 265-283, 2004. doi:10.1016/j.sedgeo.2003.11.011

[2] Komac, B., Geografski vidiki nesreče (Geographical aspects of the disaster). Ujma 14-15, pp. 60-66, 2001.

[3] Komac, B., Drobirski tok pod Mangartom (Debris flow below Mt. Mangart). Vodniki Ljubljanskega geografskega društva 3, ed. D. Kladnik, Založba ZRC: Ljubljana, pp. 95-106, 2003.

[4] Komac, B. \& Zorn, M., Recenti pobočni procesi v Zgornjem Posočju (Recent slope processes in the Upper Soča valley). Geografski obzornik 49(1), pp. 10-17, 2002.

[5] Komac, B. \& Zorn, M., Pobočni procesi in človek (Slope processes and a man). Založba ZRC: Ljubljana, 2007. 
[6] Majes, B., Analiza plazu in možnosti njegove sanacije (Analysis of landslide and its rehabilitation). Ujma 14-15, pp. 80-91, 2001.

[7] Majes, B., Petkovšek, A. \& Logar, J., Primerjava materialnih lastnosti drobirskih tokov iz plazov Stože, Slano blato in Strug (The comparison of material properties of debris flows from Stože, Slano blato and Strug landslides). Geologija 45(2), pp. 457-463, 2002.

[8] Mikoš, M., Četina, M. \& Brilly, M., Hydrologic conditions responsible for triggering the Stože landslide, Slovenia. Engineering Geology 73(3-4), pp. 193-213, 2004. doi:10.1016/j.enggeo.2004.01.011

[9] Mikoš, M., Brilly, M., Fazarinc, R. \& Ribičič, M., Sediment production and delivery from recent large landslides and earthquake-induced rock falls in the Upper Soča River Valley, Slovenia. Engineering Geology 86(2-3), pp. 1-13, 2006. doi:10.1016/j.enggeo.2006.02.015

[10] Natek, K., Komac, B. \& Zorn, M., Mass movements in the Julian Alps (Slovenia) in the aftermath of the Easter earthquake on April 12, 1998. Studia Geomorphologica Carpatho-Balcanica 37, pp. 29-43, 2003.

[11] Ogrin, D., Podnebni tipi v Sloveniji (Climate types in Slovenia.). Geografski vestnik 68, pp. 39-56, 1996.

[12] Orožen Adamič, M. (ed.), Poplave v Sloveniji (Floods in Slovenia). Ljubljana: Ministrstvo za obrambo Republike Slovenije, 1992.

[13] Pavšek, M., Snežni plazovi v Sloveniji (Avalanches in Slovenia). Ljubljana: Založba ZRC, 2002.

[14] Petkovšek, A., Geološko geotehnične raziskave plazu (Geologicalgeotechnical investigations of the Stože landslide). Ujma 14-15, pp. 109 $117,2001$.

[15] Popit T. \& Košir A., Pleistocenski plaz pri Selu v Vipavski dolini (Pleistocene landslide at Selo in the Vipava valley). Geološki zbornik 17, pp. 133-138, 2003.

[16] Poročilo o uresničevanju Zakona o ukrepih za odpravo posledic plazu Stože v občini Bovec in plazov večjega obsega, nastalih na območju Republike Slovenije po 15. oktobru 2000. Poročevalec Državnega zbora Republike Slovenije 66(118), 2001.

[17] Ribičič, M., Značilnosti drobirskega toka Stože pod Mangartom (Debris flow at Log pod Mangartom). Ujma 14-15, pp. 102-108, 2001.

[18] Ritter, D.F., Kochel, R.C. \& Miller, J.R., Process geomorphology. Dubuque: Brown Publishers, 1995.

[19] Tropeano, D., Turconi, L. \& Sanna, S., Debris flows triggered by the 29 august 2003 cloudburst in Val Canale, eastern Italian Alps. International Congress Interpraevent 1, pp. 121-132, 2004

[20] Ulaga, F., Koncentracija suspendiranega gradiva v vodotokih (Suspended load concentration in Slovene streams). Mesečni bilten 7(11), pp. 37-39, 2000.

[21] Zorn, M., Rockfalls in Slovene Alps. Acta geographica Slovenica 42, pp. 122-160, 2002.

[22] Zorn, M., Komac, B., Pobočni procesi in drobirski tok v Logu pod Mangartom (Slope processes and the debris flow in Log pod Mangartom). Geografski vestnik 74(1), pp. 9-23, 2002. 